\title{
SECONDARY COMPLICATIONS AND ASSOCIATED INJURIES IN TRAUMATIC AND NON-TRAUMATIC SPINAL CORD INJURY PATIENTS
}

Milicevic Sasa ${ }^{1}$, Bukumiric Zoran ${ }^{2}$, Karadzov Nikolic Aleksandra ${ }^{3}$, Sekulic Aleksandra ${ }^{1}$, Stevanovic Srbislav ${ }^{1}$, Jankovic Slobodan ${ }^{4}$

${ }^{1}$ Clinic for Rehabilitation "Dr M. Zotović", Sokobanjska 13, Belgrade

${ }^{2}$ Medical Faculty in Pristina, Institute of Medical Statistics and Informatics, Kosovska Mitrovica ${ }^{3}$ Institut of Reumatology, Resavska 69, Belgrade

${ }^{4}$ Medical Faculty in Kragujevac, Institute of Pharmacology, Kragujevac

\author{
SEIKUNDARNE KOMPLIKACIJE I UDRUŽENE POVREDE \\ KOD PACIJENATA SA TRAUMATSKIM I NETRAUMATSIKIM \\ POVREDAMA KIČMENE MOŽDINE \\ Milićević Saša1, Bukumirić Zoran2, Karadžov Nikolić Aleksandra3, Sekulić Aleksandra1, Stevanović Srbislav1, Janković Slobodan4 \\ 1 Klinika za rehabilitaciju „Dr M. Zotović“, Sokobanjaska 13 Beograd \\ 2 Medicinski fakultet u Prištini, Institut za medicinsku statistiku i informatiku, Kosovska Mitrovica \\ 3 Institut za reumatologiju, Resavska 69 Beograd \\ 4. Medicinski fakultet u Kragujevcu, Katedra za farmakologiju, Kragujevac
}

Received / Primljen: 15. 02. 2012

Accepted / Prihvaćen: 16. 03. 2012.

\begin{abstract}
Objective: To assess the occurrence secondary complications and associated injury following spinal cord injury (SCI) during inpatient rehabilitation.
\end{abstract}

Design: retrospective study.

Subjects: A total of 441 persons with a spinal cord injury admitted to specialized rehabilitation center.

Methods: Clinic for rehabilitation "Dr M. Zotovic", Belgrade, Serbia, from January 2000 to December 2009.

Results: Complications during rehabilitation were reported in 368 (83.4\%) patients. Complications during rehabilitation were experienced by 127 (78.4\%) patients with non-traumatic SCI(NTSCI) and 241 (86.4\%) patients with traumatic SCI (TSCI). The most common complications in both groups were urinary tract infections $(47.5 \%$ in TSCI and $64.2 \%$ in NTSCI patients), spasticity (56.8\% in NTSCI and $53.8 \%$ in TSCI patients) and decubital ulcers (9.9\% in NTSCI and $17.6 \%$ in TSCI patients). Associated injuries were present in 110 (24.9\%) patients and 331 (75.1\%) patients were without them. The most common associated injuries were: head injuries (38.5\%), followed by rib injuries (34.4\%), injuries of upper and lower extremities (21.9\%), injuries of internal organs $(4,4.2 \%)$ and pelvic injuries (1, 1\%). Associated injuries were found only in traumatic group of patients.

Conclusion: Complications are common following spinal cord injury during rehabilitation. They need specific attention after discharge from inpatient rehabilitation.

Key words: Secondary complications, associated injury, spinal cord injury, rehabilitation

\section{SAŽETAK}

Uvod : sekundarne komplikacije $i$ udružene povrede igraju veliku ulogu u funkcionalnom oporavku, morbiditetu, mortalitetu $i$ dužini boravka kod pacijenata sa povredom kičmene moždine.

Cilj: utvrditi učestalost sekundarnih komplikacija $i$ urduženih povreda kod pacijenatasa sa povredama kičmene moždine u toku rehabilitacije.

Metod: ovaj rad predstavlja retrospektivnu studija koja je obuhvatila 441 pacijenta sa povredom kičmene moždine koji su rehabilitovani u Klinici za rehabilitaciju "Dr M. Zotović" u Beogradu u periodu od januara 2000. do decembra 2009. godine.

Rezultati: komplikacije za vreme rehabilitacije je imalo 368 (83.4\%) pacijenata. Od ukupnog broja pacijenata komplikacije je imalo 127 (78.4\%) pacijenata sa netraumatskim $i$ 241 (86.4\%) pacijenata sa traumatskim povredama kičmene moždine. Najčešce koplikacija kod obe grupe pacijenata su bile: urinarne infekcije (47.5\% kod traumatskih $i$ 64.2\% kod pacijenata sa netraumatskim povredama kičmene moždine), spasticitet (56.8\% kod netraumatskih i 53.8\% kod pacijenata sa traumatskim povedama) i dekubitalni ulkusi (9.9\% kod netraumatskih $17.6 \%$ kod pacijenata sa traumatskim povredama). Od ukupnog broja pacijenata udružene povrede je imalo 110 (24.9\%) pacijenata. Najčešće udružene povrede su bile: povrede glave (38.5\%), povrede rebara (34.4\%), povrede gornjih $i$ donjih ekstremiteta (21.9\%), povrede unutrašnjih organa (1.4\%) i povrede karlice (1.1\%). Udružene povrede su se javljale samo kod pacijenata sa traumatskim povredama kičmene moždine.

Zaključak: sekundarne komplikacije i udružene povrede su često kod pacijenata sa povredom kičmene moždine u toku rehabilitacije. Adekvatna nega u kućnim uslovima može smanjiti procenat komplikacija.

Ključne reči : sekundarne komplikacije, udružene povrede, povrede kičmene moždine, rehabilitacija 


\section{INTRODUCTION}

Secondary complications and associated injuries have significant influence on health, quality of life and social participation in patients with spinal cord injury (SCI) (1-4). It has been estimated that approximately 11000 individuals have traumatic spinal cord injury in the United States each year and 262000 patients live with complications of spinal cord injury (1). With this in mind, an increased understanding of the clinical challenges associated with their care is very important (2). Increased morbidity as a result of secondary complications or associated medical conditions can play a significant role in their ongoing clinical management, functional outcomes, length of stay, and cost of care (3).

Complications have a considerable impact on those with SCI. A high incidence of complications is associated with a lower level of health-related aspects, such as physical capacity, activities and functional outcome (4). Complications may interfere with the start of active rehabilitation, can form a disappointing set-back during rehabilitation, and frequently lead to re-hospitalization (5). Diagnosis of secondary complications especially of infectious etiologies can be problematic in patients with SCI. Depending on the neurological level and completeness of injury, patients with SCI may present with diminished clinical signs and symptoms to assist in the diagnostic workup. Reasons for this include weakness of the abdominal muscles leading to diminished cough, and decreased sensation of painful symptoms (such as dysuria or discomfort from wound or bone infections (6). Additionally, complications are an important cause of mortality following SCI (7). Previous studies have investigated complications following $\mathrm{SCI}$ and their risk factors. They have illustrated the association between subject and lesion characteristics and the occurrence of complications $(8,9)$.

The aim of this study was to investigate and compare associated injuries and secondary complications during rehabilitation in traumatic and non-traumatic SCI patients (9).

\section{MATERIAL AND METHODS}

This is a retrospective study of 441 patients with the spinal cord injury treated in the Clinic for rehabilitation "Dr M. Zotovic", Belgrade, Serbia, from January 2000 to December 2009. For all patients, a detailed hospital history was taken. These hospital records were used to classify the following: age, gender, etiology of injury, neurological level of injury, associated injuries and secondary complications. The following criteria for conducting the study: $1^{\text {st }}$ all patients diagnosed with spinal cord injuries, $2^{\text {nd }}$ all patients with spinal cord injury that resolute gave signs of neurological lesions of spinal cord. Criteria for exclusion from the study: $1^{\text {st }}$ any kind of deterioration in the underlying that resulted in termination of rehabilitation provided, $2^{\text {nd }}$ patients younger than 18 years.
The diagnosis of associated injuries and secondary complications was based on both clinical features and relevant investigations when necessary. Secondary complications diagnosis was based on clinical and other diagnostic methods during hospitalization. Other specialists were consulted for treatment of secondary complications.

The patients in this study were divided into two groups based on the etiology of the injury as traumatic and nontraumatic SCI. During hospitalization the patients were assessed by the following tests: (1) ASIA scale (American Spinal Injury Association impairment scale) to assess motor and sensory levels of injury and completeness of injury and (2) MAS score (Modified Aschworth Score) to determine the level of spasticity $(10,11)$. Data were analyzed for frequency. The data is presented in tables.

Statistical analysis: For the analysis of primary data descriptive statistical methods were used, as well as hypothesis testing methods. Among the descriptive statistical methods we have used were the central tendency (arithmetic mean, median), measures of variability (standard deviation) and relative numbers. To test hypothesis about the difference in frequency Chi - squared test and Fisher test were used. T-test and Mann-Whitney test of exact probability were used for testing hypothesis about difference of arithmetic means. The level of statistical significance in our study was set to 0.05 .

\section{RESULTS}

A total of 441 patients were assessed. Of the total number of patients, 322 (73\%) were male and 119 (27\%) female. In the present study, 36.73\% (n 163) of the SCI patients were in non-traumatic SCI patients and 63.27\% (n 279) were in traumatic SCI group.

The proportion of paraplegic patients was $74.80 \%$ in the traumatic SCI group, and $82.53 \%$ in the non-traumatic SCI patients, and there was a significant difference between these two groups $(\mathrm{p}=0.005)$. The proportion of tetraplegic patients was $25.95 \%$ and $17.63 \%$ in traumatic SCI and nontraumatic SCI patientss, respectively; and there was a significant difference between these two groups $(\mathrm{p}=0.04)$.

Associated injuries were present in $110(24.9 \%) \mathrm{pa}-$ tients and 331 (75.1\%) patients were without them. The most common associated injuries were: head injuries $(\mathrm{n}=$ $37,38.5 \%)$, followed by rib injuries $(\mathrm{n}=33,34.4 \%)$, injuries of upper and lower extremities $(\mathrm{n}=21,21.9 \%)$, injuries of internal organs $(n=4,4.2 \%)$ and pelvic injuries $(n=1,1 \%)$. Associated injuries were found only in traumatic group of patients (Table 1).

Complications during rehabilitation were reported in $368(83.4 \%)$ patients. Complications during rehabilitation were experienced by 127 (78.4\%) patients with non-traumatic SCI and 241 (86.4\%) patients with traumatic SCI. Most common complications during rehabilitation were presented in table 2 . 
Complications during rehabilitation were significantly more common in patients with traumatic SCI $(\mathrm{p}=0.03)$. The most common complications in both groups were urinary tract infections (64.2\% in traumatic and $47.5 \%$ in nontraumatic patients), spasticity (56.8\% in non-traumatic and $53.8 \%$ in traumatic patients) and pressure ulcers (9.9\% in non-traumatic and $17.6 \%$ in traumatic patients). Urinary tract infections and pressure ulcer were significantly higher in traumatic than in non-traumatic patients with SCI $(\mathrm{p}=0.001$ and $\mathrm{p}=0.028)$.

\begin{tabular}{|l|l|l|l|}
\hline Associated injury & $\begin{array}{l}\text { Non-traumatic } \\
(\mathrm{n}=162) \\
\mathrm{n}(\%)\end{array}$ & $\begin{array}{l}\text { Traumatic } \\
(\mathrm{n}=279) \\
\mathrm{n}(\%)\end{array}$ & $\mathbf{p}$ \\
\hline Head & $0(0 \%)$ & $37(13,3 \%)$ & $<\mathbf{0 , 0 0 1}$ \\
\hline Ribs & $0(0 \%)$ & $33(11,8 \%)$ & $<\mathbf{0 , 0 0 1}$ \\
\hline Pelvic & $0(0 \%)$ & $1(0,4 \%)$ & 1 \\
\hline $\begin{array}{l}\text { Upper and lower } \\
\text { extremities }\end{array}$ & $0(0 \%)$ & $21(7,5 \%)$ & $\mathbf{0 , 0 0 4}$ \\
\hline Internal organs & $0(0 \%)$ & $4(1,4 \%)$ & 0,302 \\
\hline
\end{tabular}

Table 1. Associated injury

\begin{tabular}{|l|l|l|l|}
\hline $\begin{array}{l}\text { Complications during } \\
\text { rehabilitation }\end{array}$ & $\begin{array}{l}\text { Non-traumatic } \\
(\mathrm{n}=162) \\
\mathrm{n}(\%)\end{array}$ & $\begin{array}{l}\text { Traumatic } \\
(\mathrm{n}=279) \\
\mathrm{n}(\%)\end{array}$ & $\mathbf{p}$ \\
\hline Urinary tract infections & $77(47.5 \%)$ & $\begin{array}{l}179 \\
(64.2 \%)\end{array}$ & $\mathbf{0 . 0 0 1}$ \\
\hline Pressure ulcer & $16(9.9 \%)$ & $49(17.6 \%)$ & $\mathbf{0 . 0 2 8}$ \\
\hline Contactures & $3(1.9 \%)$ & $12(4.3 \%)$ & 0.171 \\
\hline Calculosis & $4(2.5 \%)$ & $13(4.7 \%)$ & 0.249 \\
\hline Autonomic dysreflexia & $1(0.6 \%)$ & $3(1.1 \%)$ & 1 \\
\hline Respiratory complications & $5(3.1 \%)$ & $8(2.9 \%)$ & 1 \\
\hline Wound dehiscence & $0(0 \%)$ & $2(0.7 \%)$ & 0.534 \\
\hline Psychological complications & $2(1.2 \%)$ & $5(1.8 \%)$ & 1 \\
\hline Spasticity & $92(56.8 \%)$ & $\begin{array}{l}150 \\
(53.8 \%)\end{array}$ & 0.538 \\
\hline Deep venous thrombosis & $0(0 \%)$ & $5(1.8 \%)$ & 0.163 \\
\hline Kardiovaculary complica- & $0(0 \%)$ & $4(1.4 \%)$ & 0.711 \\
\hline
\end{tabular}

Table 2. Complications during rehabilitation

\section{DISCUSSION}

In our study, the number of complications in the nontraumatic SCI patients was found to be less than the number of complications in the traumatic SCI group. In one study, it has been reported that complications such as spasticity, pressure ulcers, deep venous thrombosis, and autonomic dysreflexia in non-traumatic SCI patients had been found to be less often when compared to traumatic SCI patients $(12,13)$. In this study secondary complications of the patients have been compared and evaluated between non-traumatic and traumatic SCI patients.

In this study, urinary tract infection was the most common complication in the non-traumatic SCI patients $(47.5 \%)$ and its ratio among complications in the traumatic SCI group was $64.2 \%$. Urinary tract infection was found to occur in high rates in traumatic SCI. In another study, a frequency of $52.6 \%$ and $67.1 \%$ urinary tract infection has been reported in NT and traumatic SCI patients, respectively (14). New et al. evaluated the complications of rehabilitation patients only in the non-traumatic SCI patients and found that urinary tract infection was the most common complication $(45.7 \%)(14,15)$.

Spasticity was the second most common complication in patients with SCI. In our study, the ratio of spasticity was found to be $56.8 \%$ in the non-traumatic SCI patients and $53.8 \%$ in the traumatic SCI group. In other studies, spasticity has been found in a ratio of $12.9 \%$ and $21.1 \%$ in

the non-traumatic SCI patients and $32.2 \%$ and $44.3 \%$ in the traumatic SCI group (16).

The third most common complication in our study was pressure ulcer. Pressure ulcers was found in $9.9 \%$ of the non-traumatic SCI patients and in $17.6 \%$ of the traumatic SCI patients. Another study reported this ratio to be $31.3 \%$ in the non-traumatic SCI patients and in the traumatic SCI group, it has been reported to be $41.8 \%$ and $23.7 \%(17,18)$.

Deep venous thrombosis was another type of complication that was present in a $1.8 \%$ in the traumatic SCI patients. Other studies report a frequency of $7.9 \%$ (14) and $9.8 \%$ in non-traumatic SCI patients, and $22.8 \%$ in traumatic SCI patients. Deep venous thrombosis was diagnosed with clinical and Doppler ultrasonography findings $(9,20)$.

In our study the most common associated injuries were: head injuries, followed by rib injuries, injuries of upper and lower extremities, injuries of internal organs and pelvic injuries. Associated injuries were found only in traumatic group of patients. Since the spinal cord injuries are often joined with head injuries or the injuries of other organs, even nowadays it happens that such injuries are overlooked when providing the first aid at the site of accident or during transportation (20). The development of spinal centers enables more successful taking care of, diagnosing and treatment of such injuries. Our findings about frequency of associated injuries are in accordance with previous study $(20,21)$. 


\section{CONCLUSION}

Secondary complications and associated injuries frequently occur in patients with spinal cord injury. Education, prevention and adequate curing of secondary complications may increase quality of life in persons with spinal cord injuries, their survival and functional outcomes. It also may have an important part in decreasing length of stay and cost of care of this patients.

\section{REFERENCES}

1. Cardenas DD, Hoffman JM, Kirshblum S, McKinley W. Etiology and incidence of rehospitalization after traumatic spinal cord injury: a multicenter analysis. Arch Phys Med Rehabil 2004; 85 (suppl 11):1757-1763.

2. The National Spinal Cord Injury Statistical Center, Birmingham, AL. Spinal Cord Injury: facts and figures at a glance; 2010 Available from: https://www.nscisc.uab. edu Accessed January 29, 2011.

3. Wyndaele M, Wyndaele J-J. Incidence, prevalence and epidemiology of spinal cord injury: what learns a worldwide literature survey? Spinal Cord 2006; 44: 523-529

4. Valtonen K, Karlsson AK, Alaranta H, Viikari-Juntura E. Work participation among persons with traumatic spinal cord injury and meningomyelocele1. J Rehabil Med 2006; 38: 192-200.

5. Post MW, Dallmeijer AJ, Angenot EL, van Asbeck FW, van der Woude LH. Duration and functional outcome of spinal cord injury rehabilitation in the Netherlands. J Rehabil Res Dev 2005; 42: 75-85.

6. Aito S. Complications during the acute phase of traumatic spinal cord lesions. Spinal Cord 2003; 41: 629-635.

7. DeVivo MJ, Krause JS, Lammertse DP. Recent trends in mortality and causes of death among persons with spinal cord injury. Arch Phys Med Rehabil 1999; 80: 1411-1419.

8. Hooten TM, Bradley SB, Cardenas DD, et al. Diagnosis, prevention, and treatment of catheterassociated urinary tract infection in adults: 2009 international clinical practice guidelines from the Infectious Diseases Society of America. Clin Infect Dis 2009;50: 625-663.
9. Verschueren JHM, Post MWM, S de Groot, Van der Woude LHV, Van Asbeck FVA and M Rol. Occurrence and predictors of pressure ulcers during primary inpatient spinal cord injury rehabilitation. Spinal Cord 2011; 49: 106-112.

10. American Spinal Injury Association (ASIA). International standards for neurological classification of spinal cord injury. Chicago: ASIA; 2002.

11. Bohannon, R. and Smith, M. Interrater reliability of a modified Ashworth scale of muscle spasticity. Physical Therapy 1987; 67: 206.

12. Gupta A, Taly AB, Srivastava A, Vishal S and Murali T. Traumatic vs. non-traumatic spinal cord lesions: comparison of neurological and functional outcome after inpatient rehabilitation. Spinal Cord 2008; 46: 482-487.

13. Scivoletto G, Frachi S, Laurenza L, Molinari M. Traumatic and non-traumatic spinal cord lesions: An Italian comparasion of neurological and functional otucomes. Spinal cord 2011; 49: 391-396.

14. D'Hondt F, Everaert K. Urinary trac infection in patient with spinal cord injuries. Curr Infect Dis Rep 2011; 13: 544-51.

15. New PW, Rawicki HB, Bailey MJ. Non-traumatic spinal cord injury: Demographic characteristics and complications. Arch Phys Med Rehabil 2002; 83: 996-1001.

16. McKinley WO, Tewksbury MA, Godbout CJ. Comparison of medical complications following non-traumatic and traumatic spinal cord injury. J Spinal Cord Med 2002; 25: 88-93.

17. Westerkam D, Saunders LL, Krause JS. Association of spasticity and life satisfaction after spinal cord injury. Spinal Cord 2011; 49: 990-4.

18. Chapman J. Comparing medical complications from nontraumatic and traumatic spinal cord injury. Arch Phys Med Rehabil 2000; 81: 1264.

19. Janneke Haisma A, Lucas H, Van der W, Henk Stam J, Michael Bergen P, Tebbe Sluis A, Marcel PostW and Bussmann JB. Complications following spinal cord injury occurrence and risks fakctors in a longitudinals study during and after inpatient rehabilitation. J Rehabil Med 2007; 39: 393-398.

20. Osterthun R, Post MWM, Van Asbeck FWA. Characteristics, length of stay and functional outcome of patients with spinal cord injury in Dutch and Flemish rehabilitation centres. Spinal Cord 2009; 47: 339-344. 